\title{
As defuntas apaixonadas
}

\author{
Lais Helena Teles
}

Como introduzir Théophile Gautier (1811-1872)? Como apresentá-lo de forma suficientemente interessante para que saia, mesmo que para alguns poucos, do "limbo" oitocentista em que foi deixado pela geração imediatamente posterior a sua? Ou melhor, que caminhos tortuosos me conduziram a uma de suas obras? Acredito que seja esta a melhor forma de começar...

Confesso que fui apresentada a ele por um contemporâneo seu, um literato que o admirava publicamente: Charles Baudelaire. Enfim, a fonte de origem da recomendação era por demais merecedora de crédito, para que eu a ignorasse. $\mathrm{O}$ nome ficou intencionalmente registrado, mas o encontro foi por acaso. Tive o prazer de encontrar uma seleção de três de seus contos fantásticos, em francês. Além da capa magnífica, o título: Les Mortes Amoureuses. Relutei um pouco em colocá-lo traduzido, como título desta impressão de leitura. Soava estranho. Mas aí percebí que é justamente onde Gautier quis chegar, com o título original. Também em francês, precisava soar estranho.

Como já disse, trata-se de um tipo de literatura comumente chamado "fantástico" (o que não é o mesmo que "maravilhoso"). E tal etiqueta é colocada sobre as obras de um grupo imenso de literatos, entre eles E. T. A. Hoffmann, Edgar Allan Poe, Balzac, Nerval, Guy de Maupassant, Flaubert, H. P. Lovecraft, J. Cortazar, J. L. Borges. O primeiro nome remete ao século XVIII, este último ao século XX, mas é unicamente a especificidade de Gautier que pretendo destacar neste texto....

Enfim, são estes os três contos reunidos sob o título Mortes Amoureuses: Omphale (1834), La Morte Amoureuse (1836) e por fim, Arria Marcella (1852). No fim do livro há uma leitura psicanalítica dos contos, feita pelo crítico francês Bernard Terramorsi (confesso que ela não me agradou muito, provavelmente devido ao meu escasso conhecimento da psicanálise).

Passo agora a minha leitura do primeiro texto. De acordo com o próprio autor, Omphale é uma "história rococó". Remete ao século XVIII, porque é do século XVIII a tapeçaria que amarra toda a intriga. O texto é narrado em primeira pessoa: "Naquele tempo eu era bem jovem, o que não quer dizer que hoje eu seja velho(...)" Provavelmente, "naquele tempo", o narrador beirava os 17 anos. Por razões que o leitor desconhece, havia sido deixado sob a guarda de um tio, o "cavaleiro de *** ". Com este título, Gautier explicita o que mais se precisa saber sobre o personagem do tio: tratase de um homem do ancien régime, enquanto que seu sobrinho pertence a uma

\footnotetext{
' Graduação-História/UFPR.
} 
geração um tanto atordoada, herdeira das ruínas de um mundo que seus pais ou seus tios haviam conhecido inteiro, mesmo que por pouco tempo. Ruínas. Essa palavra é fundamental neste conto, assim como nos outros três. Nosso jovem não-identificado, nosso narrador, habita um "pavilhão" construído pelo tio na época de Luís XV, no meio de um jardim. Tanto o pavilhão quanto o jardim, sem manutenção, desde Luís XV. Gautier manifesta aí uma de suas maiores habilidades literárias, chamada por um crítico francês de "arte do olhar" - a descrição do musgo tomando conta dos pilares, das ervas daninhas cobrindo o jardim, da mistura úmida e pútrida que tomava conta das paredes do pavilhão tudo é exposto de forma magistral, como num quadro. Gautier pinta seus cenários e personagens com os tons melancólicos e apagados das coisas perdidas para sempre. Ou talvez eu não devesse dizer "para sempre"... E nesse ponto volto à tapeçaria, pendurada dentro do pavilhão. Nela estava representada, no mais puro rococó, uma cena mitológica : Hércules ao pé de Onfale. O narrador percebe o anacronismo, acha engraçado, mas prende o olhar na mulher. "Mas como era atraente!" O jovem deseja aquela figura imaginária, um desejo sensual que se tornaria mais familiar se despertado pela carne. Seu desejo faz Onfale voltar à vida, passando a descer da tapeçaria todas as noites, proporcionando ao jovem a descoberta do amor. No decorrer desse tempo, ele descobre que se tratava de uma marquesa da corte de Luís XV, representada na tapeçaria como Onfale. Atordoado, mas por demais envolvido pela origem misteriosa da mulher, ele compactua com o impensável. O caso amoroso não dura muito tempo. A " Marquesa de ***" é descoberta pelo tio, que manda vender a tapeçaria. Anos depois o narrador reencontraria a amante à venda numa feira de antigüidades, e a levaria para casa. Mesmo assim, ela nunca mais voltaria à vida. $\mathrm{O}$ narrador se justifica: “(...) além do mais, não sou mais jovem ou bonito o suficiente para fazer tapeçarias descerem da parede por minha causa." Ficaria a "deliciosa lembrança" de um primeiro amor bizarro, exótico, fantástico.

O segundo conto dá título ao livro - uma escolha bem acertada, já que (pcrmitam-me antecipar um detalhe do que está por vir) todas as três personagens femininas do livro estão mortas, e apaixonadas. De qualquer forma, o narrador deste segundo conto tem nome -"Romuald". "Você me pergunta, irmão, se eu amei ; sim. É uma história singular e terrível, e mesmo tendo sessenta anos, mal ouso remexer as cinzas desta lembrança (...) De dia, eu era um padre do Senhor, casto, ocupado com preces e coisas santas ; à noite, assim que tivesse fechado os olhos, eu me tornava um jovem nobre, fino conhecedor das mulheres, de cães e cavalos, jogando dados, bebendo e blasfemando ; e quando com o nascer do dia eu acordava, era como se tivesse dormido e sonhado que era padre." E ele diz mais: "Sim, eu amei como ninguém no mundo amou, com um amor insensato e furioso, tão violento que 
me espanta saber que não arrebentou meu coração. Ah! Que noites! Que noites!" Pronto. A partir daí, Gautier completa o feitiço e prende o leitor até a última página, abusando do erotismo sugerido, de nossa fascinação pelo inexplicável, pelo absurdo. Absurdo porque a mulher por quem o jovem se apaixona é "Clarimonde", uma cortesã a quem ele está prestes a dar a extremaunção. Dentro do quarto em que ela jazia morta, uma agradável fumaça de essências orientais. Ela estava magnífica, e "a morte parecia ter-lhe dado um atrativo a mais". A descrição da morta é apaixonada, fascinante. Ele confessa se sentir como o recém-casado, entrando no quarto de núpcias para encontrar a noiva, encabulada. Ele a beija, fria, mas ela o beija de volta. Incita-o a fugir com ela, pede que largue o sacerdócio, clama ser mais importante em sua vida do que Deus. Anjo ou demônio? Depois de algum tempo vivendo com ela, num palácio em Veneza, percebe que para manter-se viva Clarimonde suga, todas as noites, um pouco de seu sangue. A esta altura, um padre mais velho vem assumir aqui o papel que o tio assumiu no conto anterior : afasta Romuald da mulher, mostrando a ele o corpo em decomposição da amada, na cova.

Sem dúvida, nesta história a necrofilia é evocada como em nenhuma outra. E este é um dos aspectos que confere ao fantástico, de Gautier, o atributo "gótico". Vale lembrar que o período em que são escritos esses contos é justamente o "auge" da literatura gótica francesa, parente do "roman noir" inglês setecentista, e uma das fontes de inspiração de autores de fim de século, como H.P.Lovecraft.

Um outro aspecto marcante em Gautier, e facilmente passível de comparação com outros românticos de sua geração, é a sensibilidade para com o passado, ou a sensação do passado que marca alguns de seus protagonistas. Isto se mostra claro no primeiro conto, no qual o jovem oitocentista consegue olhar para uma França setecentista e ali perceber algo extremamente diferente daquilo que ele vivia então. O pavilhão, o jardim, a tapeçaria, a marquesa. Estas sãos as pontes que o transportam para aquela sociedade meio extinta, meio familiar, em ruínas. O jovem tem, sim, meios de se aproximar da noção de passado que antes vigorava. Ele tem meios de achar engraçado que aqueles homens tivessem desenvoltura e vaidade suficientes, para pintarem uma cena mitológica em trajes da nobreza de Luís XV.

Essa discussão introduz o terceiro conto: Octavien, jovem francês, viaja com dois amigos para o local onde estão as ruínas de Pompéia (cujas escavações prosseguiam desde 1748). Enquanto os colegas se mostram agitados e brincalhões, ele permanece totalmente absorvido pelas ruínas. Envolvido num turbilhão de nostalgia, confuso por sentir saudades de algo que não viveu, mergulha na mais profunda melancolia. Fica ainda mais sensibilizado quando se depara com um busto de mulher, esculpido em lava. O busto de uma romana -Arria Marcella, que tinha estado viva sobre a terra há mais ou menos 
dezenove séculos. Como é de se esperar, conhecendo os contos anteriores, o jovem literalmente se apaixona por aquelas formas "perfeitas", sobreviventes do desastre, do tempo.

A esta altura fica claro que, nos heróis dos quais falamos, nada mundano haveria de despertar o menor interesse, movidos como eram por visões do distante, do impensável.

Gautier esteve em Pompéia. Mas sua descrição da cidade, voltando à vida, é tão fascinante quanto aquela dos sítios arqueológicos. São ressuscitadas as pessoas, o que vestiam, onde moravam, como se comportavam -um belo trabalho de "reconstituição" por parte do autor. E como era de se esperar, o jovem finalmente encontra a romana em "carne e osso". No entanto, como nos outros dois contos, uma personagem externa vem perturbar o caso amoroso: desta vez o pai da moça (!) No entanto, existe aqui uma diferença fundamental com relação às histórias anteriores. $\mathrm{O}$ leitor não recebe nenhuma explicação quando Onfale salta da tapeçaria, e tampouco quando Clarimonde ressuscita. Só posso supor que, neste caso, a explicação tenha sedo exigida do autor, por se tratar da ressurreição de toda uma cidade...O fenômeno seria possível, porque "Nada morre, tudo continua sempre existindo; nenhuma força pode extinguir aquilo que uma vez foi (...)". Ou seja, para Gautier não há tais coisas como presente, passado ou futuro: tudo é ao mesmo tempo, porém em dimensões diferentes. Justamente isso nos tornaria insensíveis ao turbilhão...Arria existia ao mesmo tempo que Octavien, o que este último ignorava até que se sentisse suficientemente sensibilizado para ver.

Enfim, o que Gautier nos oferece, é um tipo de literatura fantástica que hoje já não é produzida. De suas viagens ao norte da África, à Itália e ao Oriente Médio, ele trouxe um gosto pelo exótico, místico e ingênuo, que o nosso conhecimento do mundo já não nos permite experimentar "concretamente". Os três contos aqui reunidos são um exemplo de uma das vias, provenientes da ficção, que podem nos conduzir a este "choque" de experiências de vida, extremamente produtivo e estimulante.

Por fim, vale lembrar que meu objetivo máximo, na construção desta impressão de leitura, foi expor alguns poucos fragmentos do imenso universo criativo contido na obra deste romântico um tanto marginalizado - o que nos tornaria mais aptos a interpretá-la, a realizar um ato criativo a partir dela. É justamente isso que espero ter conseguido proporcionar.

$$
\text { *k* } k_{3}
$$

GAUTIER, Théophile. Les Mortes Amoureuses. Paris: Éditions Babel, 1996. 